\title{
Analisis Pengelolaan Pakan Kambing Peternakan Rakyat di Desa Sindang Agung, Kecamatan Tanjung Raja, Kabupaten Lampung Utara
}

\section{Analysis of Goat Feed Management Traditional Farm in Sindang Agung Village, Tanjung Raja District, North Lampung Regency}

\author{
R Anggaraeni ${ }^{1}$, R Noviadi ${ }^{1 *}$, dan Y Sukaryana ${ }^{1}$ \\ ${ }^{1}$ Jurusan Peternakan Politeknik Negeri Lampung, \\ Jln. Soekarno Hatta No 10 Rajabasa Bandar Lampung, 35144 \\ *E-mail korespondensi: riko_noviadi@polinela.ac.id
}

\begin{abstract}
This study aims to analyze the management of goat feed carried out in Sindang Agung Village, Tanjung Raja District, North Lampung Regency. This research was conducted for 2 months in Sindang Agung Village through a survey method with qualitative field analysis. research shows that the management of goat tenak feed carried out in Sindang Agung Village is still done traditionally, where goats are only kept in pens and feed is carried out by the breeders continuously. Feeding goats that only relies on the available forage in the form of field grass, leaves on plantation land and on the side of the road in Sindang Agung Village. Farmers in Sindang Agung Village do not provide additional feed such as concentrate or other additional feed, Feeding goats is carried out in the morning and evening by means of cut and carry.
\end{abstract}

Keywords: goat feed, management, traditional farm

Diterima: 18 September 2020, disetujui 8 Desember 2020

\section{PENDAHULUAN}

Kambing adalah salah satu jenis ternak ruminansia yang merupakan penghasil daging, susu dan juga kulit serta merupakan jenis ternak yang sudah lama dibudidayakan dimasyakat. Tingkat konsumsi daging kambing di Indonesia meningkat seiring dengan pertumbuhan dan perkembangan penduduk serta bertambahnya pengetahuan masyarakat akan mengonsumsi daging. Tingkat konsumsi daging kambing masyarakat Indonesia mencapai 18.208.017 ton tahun 2017;18.306.476 ton tahun 2018; 18.975.955 ton tahun 2019 (Badan Pusat Statistik, 2020). Kambing relatif cepat untuk dikembangbiakan dan merupakan salah satu jenis ternak yang hampir selalu ada di desa. Namun sebagian dari masyarakat di desa ada juga yang menjadikan usaha ternak kambing sebagai salah satu sumber peningkatan ekonomi keluarga (Nuryanto, 2020). Umumnya, peternakan kambing di Indonesia diusahakan oleh masyarakat sebagai pekerjaan sambilan dan sistem pemeliharaannya masih tradisional, pakan yang diberikan seadanya, sehingga produktivitas yang tinggi sulit dicapai (Purbowati et al., 2015). Pengelolaan pakan yang diberikan pada ternak kambing sering tidak diperhatikan oleh masyarakat mulai dari jadwal pemberian pakan, jenis pakan yang diberikan juga konsumsi pakan yang dibutuhkan. Pemeliharaan yang dilakukan oleh peternak rakyat dengan sistem pemberian pakan yang tidak teratur seperti jumlah pakan yang harus diberikan dan waktu pemberian pakan yang dilakukan ketika kambing lapar merupakan salah satu masalah yang sering terjadi di kalangan masyarakat pedesaan seperti di Desa Sindang Agung Kecamatan Tanjung Raja Kabupaten Lampung Utara. Sehingga penelitian ini 
bertujuan untuk menganalisis pengelolaan pakan kambing peternak rakyat di Desa Sindang Agung Kecamatan Tanjung Raja Kabupaten Lampung Utara.

\section{METODE PENELITIAN}

Alat yang digunakan adalah kuesioner, tali tambang, karung dan timbangan digital dengan kapasitas $100 \mathrm{~kg}$. Bahan yang digunakan yaitu ternak kambing dan pakan kambing yang digunakan oleh peternak kambing. Metode pengumpulan data menggunakan beberapa cara sebagai berikut:

1. Wawancara, teknik ini digunakan untuk mengumpulkan data primer dengan wawancara langsung kepada responden yaitu pemilik usaha ternak kambing berdasarkan pertanyaan (kuisioner) yang telah dipersiapkan.

2. Observasi, dilakukan dengan mengamati langsung objek yang akan diteliti yaitu usaha ternak kambing seperti kegiatan pemberian pakan ternak kambing sampai sistem pengelolahan pakan ternak kambing.

3. Studi literatur, dilakukan untuk menganalisis objek penelitian secara teoritis terhadap masalah-masalah yang berhubungan dengan penulisan, melalui studi pustaka berbagai jurnal ilmiah dan skripsi, artikelartikel yang relevan, serta sumber lain yang mendukung data sekunder.

Peubah yang diamati pada penelitian meliputi gambaran umum lokasi penelitian, gambaran umum responden, manajemen pengelolaan pakan, kandungan nutrisi hijauan, pertumbuhan bobot tubuh ternak kambing.

\section{HASIL DAN PEMBAHASAN}

\section{Keadaan Umum Responden}

Umur berperan sangat penting dalam menjalankan usaha karena mempengaruhi pola bekerja dan produktifitas seseorang. Berikut adalah data keadaan responden berdasarkan umur dapat dilihat pada Tabel 1. Tabel 1. Karakteristik responden berdasarkan umur.

\begin{tabular}{ccc}
\hline Umur (tahun) & Jumlah (jiwa) & Persentase $(\%)$ \\
\hline$<30$ & 2 & 15 \\
$31-50$ & 7 & 54 \\
$>50$ & 4 & 31 \\
\hline
\end{tabular}

Sumber : Hasil Pengelolaan data Kuesioner (2020)

Tabel 1 menunjukan bahwa responden dengan usia produktif memiliki persentase paling tinggi yaitu usia $31-50$ tahun. Hal ini menunjukan bahwa tingginya angka persentase usia produktif akan berkontribusi untuk meningkatkan usaha peternakan sehingga dapat memacu pertumbuhan dan perkembangan usaha peternakan kambing di Desa Sindang Agung. Kelompok umur produktif masih mempunyai kemampuan tenaga dan pikiran untuk menunjang perkembangan usahanya. Abdullah et al. (2012) menyatakan bahwa faktor umur biasanya dikaitkan dengan tingkat produktivitas kerja, apabila seseorang masih tergolong pada usia produktif (20-45 tahun), umumnya rasa ingin tahu dan daya adopsinya terhadap teknologi semakin tinggi, dalam hal ini peternak yang memiliki usia produktif akan memaksimalkan pemeliharaan yang dilakukan dan akan menggali informasi tentang penggunaan pakan dan pengelolaan pakan yang dibutuhkan ternak.

Lama beternak juga dapat mempengaruhi jumlah skala kepemilikan ternak yang dimiliki oleh peternak. Karakteristik responden bedasarkan lamanya pemeliharaan disajikan pada Tabel 2. 
Anggraeni dkk. : Analisis Pengelolaan Pakan Kambing Peternakan Rakyat di Desa Sindang Agung, Kecamatan Tanjung Raja, Kabupaten Lampung Utara /Peterpan 2 (2): 51-55

Tabel 2. Karakteristik responden berdasarkan lamanya pemeliharaan

\begin{tabular}{ccc}
\hline Lamanya & Jumlah (jiwa) & Persentase (\%) \\
\hline$<2$ tahun & 1 & 8 \\
$2--4$ tahun & 5 & 38 \\
$>4$ tahun & 7 & 54 \\
\hline
\end{tabular}

Sumber : Hasil Pengelolaan data Kuesioner (2020)

Berdasarkan Tabel 2 peternak yang memelihara ternak kambing selama lebih dari 4 tahun memiliki persentase yang paling besar. Peternak yang sudah lama beternak memiliki pengalaman dalam mengembangkan usaha peternakan, seperti halnya di Desa Sindang Agung. Peternak yang memiliki ternak lebih banyak cukup berantusias dalam mendapatkan informasi terkait manajemen pemeliharaan ternak kambing agar mendapatkan pertumbuhan bobot tubuh yang baik dan menghasilkan daya jual yang tinggi.

Pendapat Riswandi dan Muslima (2018), bahwa peternak yang sudah lama memelihara ternak akan lebih berpengalaman dalam mengembangkan usaha ternak kambing dan akan lebih cepat menyerap inovasi teknologi dibandingkan dengan peternak yang baru atau yang kurang pengalaman. Skala kepemilikan kambing juga berpengaruh dalam memacu peternak untuk mengembangkan usaha ternak kambing. Peternak yang memiliki ternak yang lebih besar akan mengoptimalkan usahanya. Hal tersebut dapat dilihat pada Tabel 3.

Tabel 3. Kepemilikan ternak kambing

\begin{tabular}{cccc}
\hline & $\begin{array}{c}\text { Skala } \\
\text { Kepemilikan }\end{array}$ & Jumlah & $\begin{array}{c}\text { Persentase } \\
(\%)\end{array}$ \\
\hline & $1-5$ & 4 & 30,76 \\
& $6-10$ & 7 & 53,84 \\
& $>11$ & 2 & 15,38 \\
\hline Total & & 13 & 100,00 \\
\hline
\end{tabular}

Sumber : Hasil Pengelolaan data Kuesioner (2020)

Peternak yang memiliki ternak dalam skala yang lebih besar akan lebih termotivasi dibandingkan dengan peternak yang masih memiliki skala kecil. Hal ini dikarenakan peternak yang memiliki ternak lebih sedikit masih sulit menerima inovasi salah satunya pengelolaan pakan agar dapat dimanfaatkan menjadi bahan pakan dalam jangka panjang seperti pengolahan hijauan menjadi pakan fermentasi. Sesuai dengan pendapat Mardikanto (2009), bahwa semakin bertambahnya jumlah ternak yang dimiliki akan berpengaruh terhadap cara berpikir peternak untuk menerima inovasi dalam menunjang keberhasilan usahanya, karena peternak cenderung memiliki kemampuan ekonomi yang cukup baik.

\section{Manajemen Pengelolaan Pakan}

Peternak di Desa Sindang Agung masih menerapkan pemeliharaan secara tradisional yang memanfaatkan hijauan yang berada di sekitar lingkungan tempat tinggalnya serta kendaraan roda dua untuk membawa hijauan dari lahan menuju kandang ternak kambing. Sesuai dengan pendapat Riswandi dan Muslima (2018) , bahwa usaha ternak kambing di Indonesia masih dilakukan secara tradisional dengan manajemen pemberian pakan cut and carry yang bersifat usaha sambilan bagi peternak sehingga produksi yang dihasilkan belum maksimal. 
Penyedian pakan kambing secara terus- menerus dengan waktu pemberian pakan dua kali dalam sehari yaitu pada pagi dan sore, pakan yang disediakan dipotong oleh peternak pada pagi dan sore hari, kemudian diletakan di samping atau di depan kandang ternak. Pakan hijauan yang ditumpuk atau diikat akan mengalami kerusakan pada bagian tertentu, contohnya hijauan yang diletakan dalam karung dengan jangka waktu yang lama akan mengalami kebusukan dibagian bawah. Hijauan yang akan menjadi stok pakan sebaiknya memiliki ruang yang sama dan mendapatkan udara dan sinar matahari yang sama.

Pengelolaan pakan yang baik perlu dilakukan untuk memperbaiki kualitas pakan yang diberikan kepada ternak. Penyediaan hijauan pakan ternak kambing dengan sistem cut and carry dilakukan sekitar pukul 07.00--08.00 WIB dan pukul 17.00 WIB, pemberian pakan dilakukan tanpa melalui penjemuran dan pencacahan terlebih dahulu serta tidak ada pakan tambahan yang diberikan pada ternak kambing. Waktu pemberian pakan berpengaruh terhadap pertumbuhan bobot tubuh ternak kambing sesuai dengan hasil penelitian Rudiah (2011) bahwa waktu pemberian pakan berpengaruh sangat nyata terhadap pertambahan bobot badan dan efisiensi penggunaan pakan ternak kambing.

\section{Pertambahan Bobot Badan Harian (PBBH)}

Pertambahan bobot tubuh harian ternak kambing yang berada di Desa Sindang Agung merupakan salah satu aspek yang dapat dilihat dari hasil pengelolaan pakan yang dilakukan oleh peternak karena jika pengelolaan pakan dilakukan dengan benar maka akan menghasilkan PBBH yang tinggi namun jika pengelolaan pakan yang dilakukan masih sembarang maka akan menghasilkan PBBH yang rendah. Rataan pertambahan bobot tubuh ternak kambing disajikan pada Tabel 4.

Tabel 4. Rata-rata pertambahan bobot tubuh ternak kambing

\begin{tabular}{lccc}
\hline \multicolumn{1}{c}{ Jenis Kambing } & $\begin{array}{c}\text { Bobot Awal } \\
(\mathrm{kg})\end{array}$ & $\begin{array}{c}\text { Bobot Akhir } \\
(\mathrm{kg})\end{array}$ & $\begin{array}{c}\text { PBBH } \\
(\mathrm{kg})\end{array}$ \\
\hline Kambing Kacang Jantan & 17,40 & 20,42 & 0,050 \\
Kambing Kacang Betina & 15,54 & 18,89 & 0,056 \\
Kambing PE Jantan & 30,27 & 34,00 & 0,062 \\
Kambing PE Betina & 32,40 & 36,60 & 0,041 \\
\hline
\end{tabular}

Sumber : Hasil Pengolahan data Kuesioner (2020)

Tabel 4 tersebut menunjukan bahwa hasil penelitian yang dilakukan di Desa Sindang Agung masih memiliki Pertambahan bobot tubuh harian yang rendah jika dibandingkan dengan penelitian Purbowati et al. (2015), pertambahan bobot tubuh harian kambing kacang jantan yang diberi pakan hijauan dari tanaman kaliandra, mahoni, suren, gamal, dan albasia pada umur muda ( $\leq 6$ bulan) sebesar 71,20 g/ekor/hari dan pada umur dewasa (> 6 bulan) sebesar 42,30 gram/ekor/hari. Begitu pun dengan kambing kacang betina, kambing PE jantan dan kambing PE betina memiliki pertambahan bobot tubuh harian yang rendah jika dibandingkan dengan penelitian Purbowati et al. (2015).

\section{KESIMPULAN}

Analisis pengelolaan pakan kambing peternak rakyat di Desa Sindang Agung Kecamatan Tajung Raja Kabupaten Lampung Utara, bahwa pengelolaan pakan kambing masih secara tradisional hanya dengan memanfaatkan pakan hijauan yang berada di sekitar lingkungan masyarakat, penyediaan pakan menggunakan sistem potong angkut (cut and carry) yang dilakukan oleh peternak dan pemberian pakan tanpa proses pemotongan atau pencacahan serta tidak ada penambahan pakan konsentrat maupun pakan tambahan lain. 
Anggraeni dkk. : Analisis Pengelolaan Pakan Kambing Peternakan Rakyat di Desa Sindang Agung, Kecamatan Tanjung Raja, Kabupaten Lampung Utara /Peterpan 2 (2): 51-55

\section{DAFTAR PUSTAKA}

Abdullah, A., Aminawar, M., Hoddi, A.H., Ali, H.M., dan Syamsu, J.A . 2012. Identifikasi Kapasitas Peternakan dalam Adopsi Teknologi untuk Pengembangan Sapi Potong yang Terintegrasi dengan Padi. Prosiding Seminar Nasional Peternakan Berkelanjutan IV "Inovasi Agribisnis Peternakan untuk Ketahanan Pangan”. Fakultas Peternakan, Universitas Padjadjaran. Bandung.

Badan Pusat Statistik [BPS]. 2020. Peternakan dalam Angka. Badan Pusat Statistik: Jakarta.

Mardikanto, T. 2009. Sistem Penyuluhan Pertanian. UNS Press: Surakarta.

Nuryanto, M. 2020, Pengaruh Pengelolaan Wirausaha Ternak Kambing dalam Meningkatan Ekonomi Keluarga (Studi Pada Usaha Ternak Kambing di Desa Sumberrejo, Kecamatan Batanghari, Kabupaten Lampung Timur). Skripsi. Institut Agama Islam Negeri (IAIN) Metro.

Purbowati, E., Rahmawati, I. dan Rianto, E. 2015. Jenis hijauan pakan dan kecukupan nutrien kambing jawarandu di Kabupaten Brebes Jawa Tengah. Pastura 5(1): 10-14.

Riswandi dan G.A. Muslima. 2018. Manajemen pemberian pakan ternak kambing di Desa Sukamulya Kecamatan Indralaya Utara Kabupaten Ogan Ilir. Jurnal Peternakan Sriwijaya. 7 (2): 24--32.

Rudiah. 2011. Respon kambing kacang jantan terhadap waktu pemberian pakan. Media Litbang Sulteng IV(1): $67-74$. 